\title{
School effectiveness and student cheating: Do students' grades and moral standards matter for this relationship?
}

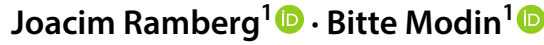 \\ Received: 9 January 2019 / Accepted: 22 February 2019 / Published online: 8 April 2019 \\ (c) The Author(s) 2019
}

\begin{abstract}
Cheating is a more or less prominent feature of all educational contexts, but few studies have examined its association with aspects of school effectiveness theory. With recently collected data from upper-secondary school students and their teachers, this study aims to examine whether three aspects of school effectivenessschool leadership, teacher cooperation and consensus, and school ethos-are predictive of student's self-reported cheating, while also taking student- and school-level sociodemographic characteristics as well as student grades and moral standards into consideration. The study is based on combined data from two surveys: one targeting students and the other targeting teachers. The data cover upper secondary schools in Stockholm and includes information from 4529 students and 1045 teachers in 46 schools. Due to the hierarchical data, multilevel modelling was applied, using twolevel binary logistic regression analyses. Results show significant negative associations between all three aspects of school effectiveness and student cheating, indicating that these conditions are important to consider in the pursuit of a more ethical, legitimate and equitable education system. Our findings also indicate that the relationship between school effectiveness and student cheating is partly mediated by student grades and moral standards.
\end{abstract}

Keywords Student cheating $\cdot$ School effectiveness $\cdot$ Grades $\cdot$ Moral standards · Upper secondary school · Multilevel

\footnotetext{
Joacim Ramberg and Bitte Modin have contributed equally to this manuscript.
}

Joacim Ramberg

joacim.ramberg@su.se

1 Department of Public Health Sciences, Centre for Health Equity Studies (CHESS), Stockholm University/Karolinska Institutet, Sveavägen 160, Floor 5, 10691 Stockholm, Sweden 


\section{Introduction}

Upper secondary school has been put forward as a critical period in life for people's moral and ethical development (McCabe and Trevino 1993). Although cheating in school is an essentially individual act, strongly linked to the individual's morality and ethical compass, the inclination to cheat also depends on contextual circumstances (Day et al. 2011; Wowra 2007). Thus, previous studies have shown that both individual and contextual factors play a role in student's tendency to cheat (McCabe et al. 2012).

The problem of a school's cheating prevalence can roughly be divided into two dimensions, both of which contain elements of equity and fairness. The first dimension relates to the school's obligation to provide as fair an assessment of each student's performance as possible (Lundahl 2010). This is important in its own right, but also serves as a foundation of the school's credibility when it comes to fostering the moral and ethical development of their students. The second dimension concerns the societal goals of equitable allocation of life opportunities, meaning that someone who cheat may take someone else's place in the competition for higher education and future employment. This kind of injustice becomes particularly critical during upper secondary school when students compete for places in higher education with their final grades.

Research conducted within the field of school effectiveness has pointed to the importance of school contextual features for introducing adolescents into adulthood and counteracting unwanted behaviours (Granvik-Saminathen et al. 2018; Ramberg et al. 2018a; Rutter and Maughan 2002; Teddlie and Reynolds 2000), but few studies have been carried out on the importance of school effectiveness for student cheating (McCabe et al. 2012). The existing literature is also limited regarding studies that have had the opportunity to take individual students' moral values into consideration when examining potential external causes of student cheating (Yu et al. 2017).

With data that combine student and teacher information from two separate data collections performed in 2016, comprising teachers and students in 46 upper secondary schools in Stockholm, we intend to contribute to this field of research by examining whether high teacher-ratings of three features of school effectiveness (school leadership, teacher cooperation, and school ethos) is predictive of low selfreported student cheating, while controlling for a number of social and demographic background characteristics. We will also investigate the potential mediating role of students' grades and moral standards for the studied associations.

\subsection{Student cheating}

There is no commonly accepted, standard definition of academic dishonesty (Schmelkin et al. 2008), but it usually refers to behaviours such as cheating on exams or homework tests, copying other student's homework and assignments, unauthorized cooperation with peers, and plagiarism (Arnett et al. 2002), with that in common that they are related to the individual's moral identity (Wowra, 2007). Among these different immoral behaviours, it has been shown that both students and 
teachers consider cheating on exams as the most serious breach of the rules (Bernardi et al. 2008). As with the concept of academic dishonesty, there is no commonly held definition of student cheating (McCabe et al. 2012), but several types of acts are generally included as markers of student cheating, all of which have in common that they are wrongful acts intended to improve the student's own or others' "apparent" performance. A definition in line with this can be found in the Swedish Higher Education Ordinance (2002/2010) which states that cheating refers to the use of "prohibited aids or other methods to attempt to deceive during examinations or other forms of assessment of study performance" (chapter 10, para1). Common ways of cheating on homework tests or examinations are to swap papers/answers with peers, bring crib notes, use unauthorized equipment, look at another student's test, let someone else look at their own, obtaining a copy of the test prior to taking it in class, taking a test for another student, or by failing to report grading errors of an exam (Bernardi et al.2008; Smith et al. 2002, 2004).

Numerous surveys have been conducted over the years to compile the extent of cheating at both the upper secondary and university levels, predominantly in the US. In reviews of these surveys it appears that as much as up to two thirds of college students, and even higher proportions in high school, reported some kind of cheating behaviour during their last academic year (Davis et al. 2011; McCabe et al. 2012). This picture is strengthened by findings from another study covering about 23,000 high school students (grades 9-12) in the US, where about 50 percent stated that they had cheated at least once during a test in school in the year prior to the survey (Josephson Institute 2012). Although research shows that cheating is not restricted to a certain country or geographical area, the number of studies in geographical contexts other than the US is much more limited (Davis et al. 2011; Shariffuddin and Holmes 2009). One of the few studies that compared the extent of cheating on exams between nations, based on 7,200 university students from 21 countries, found that the rates and beliefs about cheating differ by country, and that countries known to be the least corrupt had the lowest proportions of student cheating. Consequently, Scandinavian countries displayed a lower level of cheating than most other nations (Teixeira and Rocha 2010). However, to the best of our knowledge, there is no sizeable study that has examined the prevalence of academic cheating in Sweden.

\subsection{Characteristics related to student cheating}

\subsubsection{Individual characteristics}

One of the most common characteristics examined in relation to student cheating is gender. Several studies report that males are more prone to cheat and that they have more permissive attitudes towards cheating than females (e.g., Arnett et al. 2002; Hensley et al. 2013; Jereb et al. 2018). Other studies show that even though there seems to be a small direct effect of gender on student cheating, it is mainly a set of social mechanisms related to gender (e.g. shame, embarrassment, self-control) that account for the existing differences between males' and females' cheating behaviour (Gibson et al. 2008; McCabe et al. 2012; Niiya et al. 2008). 
Another variable that has been extensively investigated in relation to student cheating is academic achievement (most often operationalized as GPAs or grades). Students with lower grades tend to be more likely to cheat than those with higher grades (e.g. Burrus et al. 2007; Klein et al. 2007; McCabe and Trevino 1997). Socioeconomic background (e.g. parents' education, income and occupation), on the other hand, appears to be of less importance for student cheating according to the existing literature (Kerkvliet 1994; McCabe and Trevino 1997; Whitley 1998).

The relationship between migration background and student cheating is a complex issue and the literature is scarce. While research does not seem to point to any major disparity between different ethnic groups, students with a foreign language can experience greater difficulties in understanding the content of the education (Mori 2000), and therefore be more inclined to cheat.

As could be expected, permissive attitudes toward cheating have been found to increase the likelihood of engaging in such behaviours (Farnese et al. 2011; Whitley 1998). However, girls' cheating behaviour seem to be more strongly affected by perceiving cheating as morally wrong (Gibson et al. 2008). Furthermore, students with lower stress resistance, higher risk willingness, lower work ethic and lower motivation seem to be more likely to cheat (Davis et al. 2011). Excessive demands from parents and personal desires to excel in school have also proved to be important motivations for student cheating (McCabe et al. 1999).

\subsubsection{Contextual characteristics}

While individual characteristics and influences from the family can increase a student's incentives to cheat, the contextual conditions offered by the school can also be more or less favourable for acting upon such incentives (Nilsson et al. 2004). It is a matter of fact that students are more likely to cheat when they perceive the risk of being detected as slight, and when the consequences of potential detection are regarded as low (Bisping et al. 2008; Cizek 1999; Gire and Williams 2007; McCabe and Trevino 1993; Whitley and Keith-Spiegel 2002). For instance, schools with clearly formulated rules against cheating tend to have lower rates of such behaviour (McCabe and Trevino 1993; McCabe et al. 2001). The school's ability to detect and impose penalties for students who cheat is of course also important (McCabe et al. 2012).

One of the most influential contextual factors for cheating is the extent to which students perceive that their peers cheat (McCabe et al. 2012), that is how normalized such behaviour has become at the school. Normalization of cheating is when a permissive culture is developed through a shift in the collective attitudes of the students, whereby cheating is increasingly viewed as less blameable and morally wrong the more often individual students perceive that their peers cheat (McCabe et al. 2012; O'Rourke et al. 2010). Previous research has shown that schools with a strong focus on competition and achievement tend to invoke an increased amount of cheating among its students (Anderman and Koenka 2017; Anderman and Midgley 2004), whereas schools that emphasize the value of learning itself tend to display a lower amount of cheating (Miller et al. 2007). Taken together, the school's culture, or ethos, appears to have a crucial impact on students' inclination to cheat. 


\subsubsection{Implications of student cheating}

Cheating in school is linked to an increased risk for future unethical actions, both in further education and later working life (e.g. Carpenter et al. 2004; Graves 2011; Lucas and Friedrich 2005; Lawson 2004; Whitley 1998). Having developed a cheating behaviour in one social context is thus likely to spill over to another (Bowers 1964). Fonseca (2014) discusses the problematic consequences of student cheating in terms of two main aspects. The first concerns how ethics, morals and social trust in school become damaged through cheating, and the second concerns how the learning of an individual student is affected. Thus, student cheating means that the trust of the school as an institution for allocation of future education opportunities and positions in work life becomes weakened (Whitley and Keith-Spiegel 2002). The fact that cheating leads to a knowledge assessment of the student that is not correct also means that the student's prerequisites for continued learning is negatively affected.

\subsection{School effectiveness}

Research on school effectiveness deals with school organizational factors and the way in which they shape student's learning and behaviour. According to the theory of effective schools, certain contextual features are crucial for the school's possibility of creating positive student outcomes and for counteracting negative behaviours (e.g. Grosin 2004; Rutter et al. 1979; Sellström and Bremberg 2006). As maintained by Scheerens (2016), there is a strong consensus within the field about which school contextual factors that are of particular importance for student outcome, namely those that are concerned with a strong and clear school leadership, development of and cooperation between teachers, and the overall school ethos. These three features of school effectiveness can be understood as hierarchically ordered, where agents in the higher level of the school structure (e.g. school leadership) has the potential to influence processes at the intermediate level (e.g. teachers and other school staff), which in turn affect conditions at the lower level (i.e. students) (Blair 2002).

Studies have shown that school leadership is of great importance for student outcomes (Låftman et al. 2017; Ramberg et al. 2018a, b), but that the effects should be understood as indirect since they are often mediated through, for example, the teachers' collegial work and the culture of the school as a whole (Muijs 2011). Teacher cooperation involves conditions for meeting and creating opportunities for communication, exchange of ideas, joint planning and collegial support, which is also a prerequisite for consensus on important educational and organizational issues (Ramberg et al. 2018b; Vangrieken et al. 2015; Van Waes et al. 2016). The concept of school ethos, finally, refers to the norms, values and beliefs permeating the school and manifesting themselves in the way that teachers and students relate, interact and behave towards each other (Modin et al. 2017; Rutter et al. 1979). Research within the field of school effectiveness has pointed to the importance of these school contextual features for counteracting unwanted 
student behaviours such as bullying (Modin et al. 2017) and truancy (Ramberg et al. 2018a). It seems reasonable to assume that they also have an impact on the extent of student cheating at the school.

\subsection{The Swedish upper secondary school context and student cheating}

The Swedish upper secondary school is mainly governed by the Education Act (SFS 2010:800) and the Upper Secondary School Ordinance (SFS 2010: 2039). No specific guidelines for cheating are given in these documents, besides the fact that cheating behaviour should be treated as a disciplinary matter. Procedures for dealing with student cheating and their disciplinary actions, should be developed within the frames of each school's own rule policy. However, according to SFS (2010: 2039), it appears that principals at the upper secondary level may decide to suspend a student if he or she has used unauthorized methods or otherwise tried to mislead any assessments of their performance or knowledge. Since there are no central laws or regulations concerning student cheating, it is reasonable to assume that there is a great variation between schools in rates of cheating and the ways in which these matters are handled.

The Swedish school system in general, and upper secondary school in particular, has undergone massive reforms over the past two decades, resulting in heavily economized and market-adapted changes combined with a grade system that consists of a sharp line between approved grades and failure (Lundahl et al. 2014; Ramberg 2015). In a competitive school market, failed grades often mean that individual students will face difficulties to establish themselves in the labour market. On behalf of the school, a high proportion of failed grades means that the attractiveness of the school decreases, and that teachers risk disadvantageous wage allocations. Therefore, it is not difficult to see that all involved parties in this market-oriented school system will "fight" for approved grades in order to survive. The distinction between failed and approved grades constitutes a harsh border between failure and success for both the individual student, the teacher, and the school. The pursuit for passed grades may therefore invoke a higher degree of cheating among students as well as a higher tolerance among teachers for a school culture of cheating (Fonseca 2014).

\subsection{Aim}

The aim of the present study is to examine the relationship between three teacherrated aspects of school effectiveness-school leadership, teacher cooperation and consensus, and school ethos-and student's self-reported cheating in upper secondary school. We hypothesize that higher ratings of these effectiveness features are related to a lower degree of student cheating, even when socio-demographic background characteristics at both the student- and at the school-level as well as individual grades and moral values have been taken into consideration in the analysis. 
The following hypotheses are formulated:

H1 The teachers' ratings of each of the three features of school effectiveness (school leadership, teacher cooperation and school ethos) is negatively associated with degree of student cheating.

H2 These associations remain when controlling for sociodemographic characteristics at both the student-and school-level.

H3 Students' self-reported grades serve as a mediator in the relationship between each of the three studied school effectiveness characteristics and student cheating.

H4 Students' self-reported moral values serve as a mediator in the relationship between each of the three studied school effectiveness characteristics and student cheating.

H5 The associations between each of the three studied school effectiveness characteristics and student cheating remain also when controlling for student grades and moral values.

\section{Method}

\subsection{Data}

The study is based on data from two separate surveys, both of which were performed in 2016: the Stockholm School Survey (SSS), and the Stockholm Teacher Survey (STS). The SSS is carried out every second year by Stockholm Municipality among students in the 2nd grade of the upper secondary school (aged 17 to 18 years); henceforth called eleventh grade students $(\mathrm{N}=8324$, response rate $77.1 \%)$. All public schools are obliged to participate, whereas independent schools are invited to participate on a voluntary basis. The questionnaires are administered by teachers and filled in by the students in the classroom. The SSS covers a wide range of questions with a specific focus on alcohol, smoking, drugs and crime, but areas such as family background, personal qualities, psychological health, grades and cheating are also included. The STS was conducted by our research group, targeting all upper-secondary level teachers (grades 10-12) $(\mathrm{N}=2443$, response rate $57.9 \%)$ in Stockholm Municipality through a web-based questionnaire. The overall aim of the STS was to gather information about schools through teachers' ratings of their working conditions, the school leadership, teacher cooperation and consensus, and school ethos, and to link these school-contextual aspects to students' responses from the SSS. The two surveys were merged, which means that only schools who participated in both surveys were included, resulting in a study sample covering information from 6129 students and 1204 teachers across 58 schools. We have also linked school-level information from official records to our data (Swedish National Agency 
of Education 2016). Due to missing information in these official records, 12 schools (comprising 528 students) were lost. Additionally, students with missing information on any of the variables used in the analyses were excluded $(n=1072)$, resulting in a final study sample of 4529 eleventh grade students and 1045 upper-secondary school teachers across 46 schools.

Student data from the Stockholm School Survey were collected anonymously, and were not considered as an issue of ethical concern, according to a decision by the Regional Ethical Review Board of Stockholm (2010/241-31/5). The Stockholm Teacher Survey was approved by the Regional Ethical Review Board of Stockholm $(2015 / 1827-31 / 5)$.

\subsection{Variables}

\subsubsection{Dependent variable}

Student cheating was created from the question: 'Have you cheated on a homework test or an examination at school this year?', followed by the response options 'No'; 'Yes, once'; 'Yes, 2-3 times'; 'Yes, 4-10 times'; 'Yes, 10-20 times' and 'Yes, more than 20 times'. The variable was dichotomized into those who reported cheating $0-3$ times vs. those who reported cheating four times or more. The reason for this relatively conservative cut-off was to make certain that we only capture serious cases of cheating with this measure.

\subsubsection{Main independent variables (school-level)}

The main independent variables consist of three teacher-rated dimensions of school effectiveness: school leadership, teacher cooperation and consensus, and school ethos. These dimensions were developed from three batteries of questions in the STS meant to capture the most essential theoretical components of effective schools. All items included in the three dimensions of school effectiveness are presented in Table 1. The response alternatives for the items were: 'Strongly agree'; 'Agree'; 'Neither agree nor disagree'; 'Disagree'; and 'Strongly disagree'. In order to check if the items were related as expected, exploratory factor analysis (EFA), followed by confirmatory factor analysis (CFA) were performed. School-level means for each of the three measures were calculated and merged with student-level data, whereupon they were $z$-transformed (mean value $=0$, standard deviation $=1$ ) in order to facilitate comparison between their coefficients. Values from all items were added to form an index with higher scores indicating higher teacher ratings of the dimensions of school effectiveness. As shown in Table 1, all indices have a good or reasonably good model fit and high internal consistency.

\subsubsection{Potential confounders (school-level)}

At the school-level, five variables retrieved from the Swedish National Agency's database, are adjusted for as potential confounders: proportion of students with a 


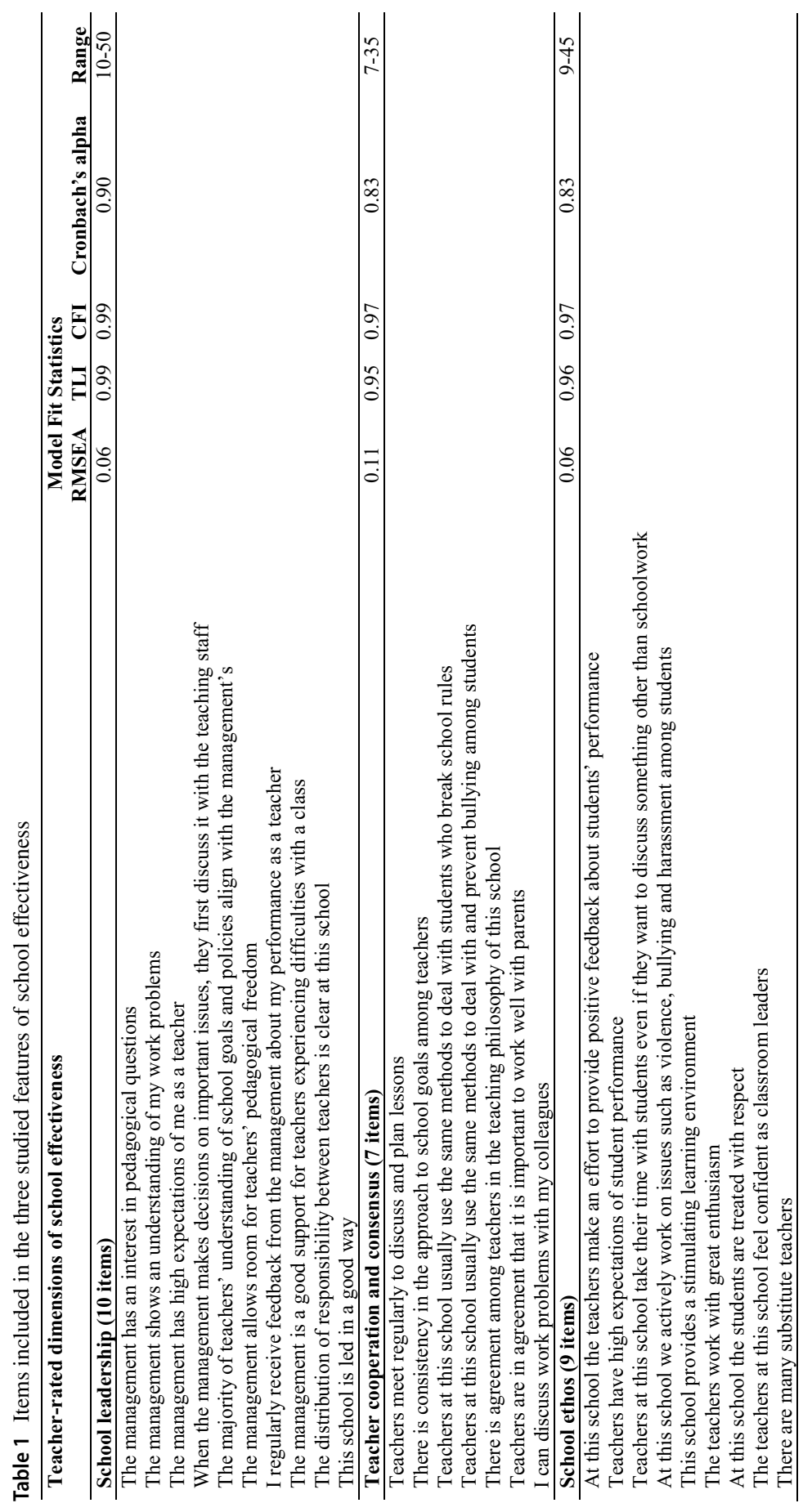


foreign background (i.e. born outside Sweden or having both parents born outside of Sweden); proportion of students with parents with post-secondary education; students-per-teacher ratio; and proportion of teachers with a pedagogical degree. School type, finally, refers to whether the school is public or independent.

\subsubsection{Potential confounders and mediators (student-level)}

Several variables at the individual level that could act as potential confounders or mediators were adjusted for in the analyses. Gender was coded as 'boy' (value 0) or 'girl' (value 1). Parental education was created from the question 'What is the highest education your parents have?' with the following response options to be ticked separately for the mother and the father: 'Compulsory'; 'Upper secondary school'; and 'University'. The variable was coded into those who reported no parent with post-secondary education or missing information (value 0 ), those with one parent with post-secondary education (value 1), and those reported having two parents with post-secondary education (value 2). Migration background was measured by asking 'How long have you lived in Sweden?' followed by the response alternatives: 'All my life'; ' 10 years or more'; ' $5-9$ years'; and 'less than 5 years'. The variable was coded into those who lived in Sweden their whole life (value 0), those who lived in Sweden ten years or more (value 1), and those reported living in Sweden less than ten years (value 2). Grades were measured as the summation of the student's self-reported grades in the foundation subjects Swedish, mathematics and English from the previous term. Grades (A-F) were given numerical values $(A=5, B=4$, $\mathrm{C}=3, \mathrm{D}=2, \mathrm{E}=1$, and $\mathrm{F}$ or no grade $=0$ ), resulting in an approximately normally distributed index ranging between 0 and 15. Moral index was created from the question 'How well do the following statements describe you as a person?' followed by the statements: 'I lie to get benefits or to get out of doing tough things'; 'I ignore rules that stop me from doing what I want to do'; 'I think it's OK to take something without asking as long as you don't get caught'; and 'It's wrong to cheat at school'. Each item had four response alternatives: 'Describes very poorly', 'Describes rather poorly', 'Describes rather well', and 'Describes very well'. The scores from each statement were summed into an index ranging between 4 and 16, with low values indicating high moral standards.

\subsection{Statistical method and analytical strategy}

Due to the hierarchical nature of the data, multilevel modelling was applied. Twolevel binary logistic random intercept models were estimated. Since studies comparing Odds Ratios (OR) between logistic regression models have been shown to be problematic (Mood 2010), we have also performed multilevel linear probability models as sensitivity analyses. The three independent variables were highly correlated $(\mathrm{r}=.68-.80)$ and were therefore analyzed in separate models to avoid multicollinearity problems (Djurfeldt and Barmark 2009). In order to estimate the variation of student cheating between schools, we first estimated an empty model with no independent variables. The Intra Class Correlation (ICC) for binary outcomes gives 
approximate information about the variance that can be ascribed to the school-level (Wu et al. 2012).

The posed hypotheses are addressed in a series of models where the assumed confounders and mediators are successively taken into consideration. Model 1 targets hypothesis 1 by examining the associations between the three independent school effectiveness variables and student cheating. The second and third models aim to answer hypothesis 2 by exploring the possible impact of confounders at the individual- and school-level. Models 4-5, investigate the mediating role of student grades and moral standards in order to answer hypothesis 3 and 4, respectively. Model 6, finally, examines whether the studied associations remain even when student grades and moral values are controlled for. In order to assess whether the goodness of fit was significantly improved when the potential mediators were added to the models, the Likelihood Ratio Test was used.

Regarding the mediation analyses, we rely on Baron and Kenny's (1986) fourstep model for testing mediation. The first step consists of making sure that the independent variable is significantly associated with the dependent variable, and the second step of ensuring that the independent variable is significantly related to the presumed mediator. In the third step, the mediator should be significantly related to the independent variable. The fourth step, finally, consists of making sure that the previously significant relationship between the independent variable and the dependent variable decreases (or becomes non-significant) when the assumed mediator is included in the model (Baron and Kenny 1986). The first three steps are examined through bivariate associations, while the final step is examined in the last three models of the regression analyses.

\section{Results}

The left-hand side of Table 2 presents descriptive statistics for all of the variables used in the analyses. About eight percent of the students in this study reported that they had cheated four or more times on a homework test or an examination during the past school year. There are slightly more girls than boys represented in the sample, and about 42 percent reported having two parents with post-secondary education, while about 25 percent reported having one parent with post-secondary education. The majority of students have lived in Sweden all of their lives, but about 17 percent report having a migration background. The mean grade in the three foundation subjects is 8.6, and the mean score on the index assessing moral values is 7. There is a substantial variation between schools in the three (unstandardized) measures of school effectiveness as indicated by their range. This is also the case for the school-level indicators of parents' educational level and foreign background. Likewise, the average teacher density and the degree of qualified teachers differ substantially between schools. About 40 percent of the students in our sample attended an independent upper secondary school, which reflects the high proportion of independent schools in the municipality of Stockholm.

The first column of the right hand side of Table 2 presents the bivariate associations between the independent variables and the studied outcome. All variables, except 
students-per-teacher-ratio and percentage of teachers with a pedagogical degree at the school, are significantly associated with student cheating. These findings also confirm the first and third steps of Baron and Kenny's (1986) model for testing mediation, namely that our main independent variables (school leadership, teacher cooperation and consensus and school ethos) as well as our hypothesized mediators (grades and moral values) are significantly associated with the studied outcome. Furthermore, the results of the bivariate analyses show a somewhat higher degree of reported cheating among students in independent schools, among boys, among students with lower parental education, and among students having lived their whole life in Sweden. The results in the two final columns of Table 2 confirm that the second step of Baron and Kenny's criteria for testing mediation is largely fulfilled as well, namely that our three main independent variables are significantly associated with the two hypothesised mediators. The only exception is the absence of a significant association between teacher cooperation and students' moral values. This means that we can already now conclude that there is no mediating effect of students' moral values in the relationship between the school's degree of teacher cooperation and student cheating.

Table 3 presents the main findings of the study in a series of five models where potential confounders (Models 2-3) and mediators (Models 4-6) at the schooland student-level are successively introduced. The empty model reveals an ICC of 0.1010 , indicating that roughly 10 percent of the variation in student cheating can be attributed to conditions at the school level. As expected, higher levels of all three teacher-rated features of school effectiveness (Model 1) are associated with lower student-reported cheating. The estimate for school leadership indicates that each standard deviation increase in leadership quality is associated with a decreased odds of student cheating corresponding to OR $=0.73$ $(p=0.003)$. The analogous estimates for teacher cooperation and school ethos are $\mathrm{OR}=0.77(p=0.012)$ and $\mathrm{OR}=0.63(p<0.001)$, respectively. Thus, school ethos is the strongest predictor of student cheating among the three studied school effectiveness features. This is also evident from the ICC values, where a larger drop in the estimate vis-à-vis the empty model can be seen for school ethos $(\mathrm{ICC}=0.0391)$ than for school leadership $(\mathrm{ICC}=0.0769)$ and teacher cooperation $(\mathrm{ICC}=0.0804)$. It thus seems like quite a large part of the observed differences between schools in student cheating operate via the school's teacher-rated ethos.

The odds ratios for all three indicators of school effectiveness remain practically unaltered when sociodemographic characteristics at both the school-level (Model 2) and student-level (Model 3) are adjusted for. Thus, even though the inclusion of these variables is associated with a further reduction of the ICC values, the adjusted odds ratios remain practically the same as in the crude model, suggesting that their confounding effect is minor. When adding grades as a potential mediator in Model 4, however, the odds ratios for student cheating decreases markedly in relation to both school leadership $(\mathrm{OR}=0.81, p=0.028)$ and school ethos $(\mathrm{OR}=0.71, p<0.001)$, indicating that students' increased tendency to cheat when their grades are low serves as a mediator between these two indicators and student cheating. When it comes to the importance of teacher cooperation for student cheating, however, grades do not seem to affect the association to the same extent. 


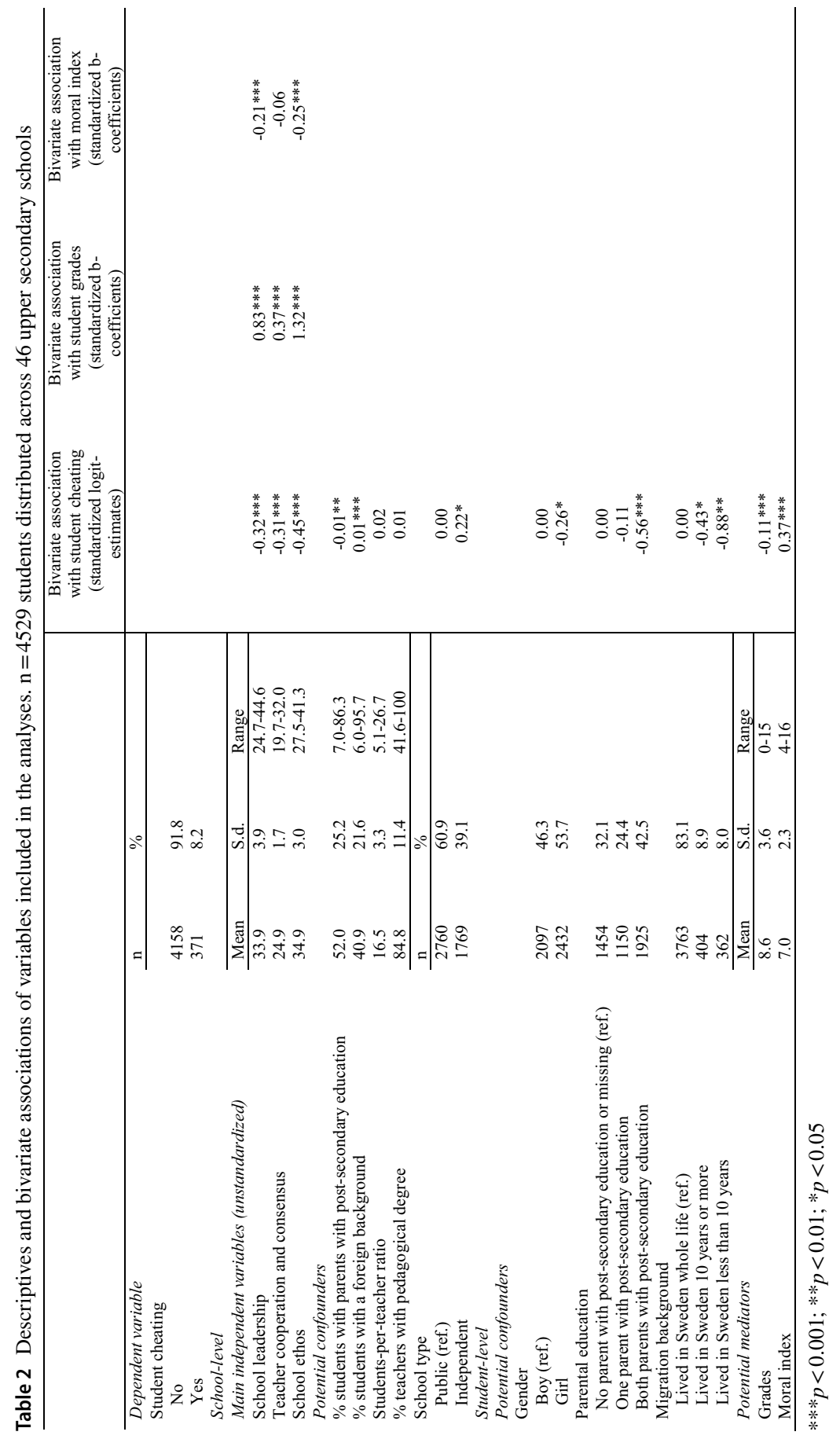




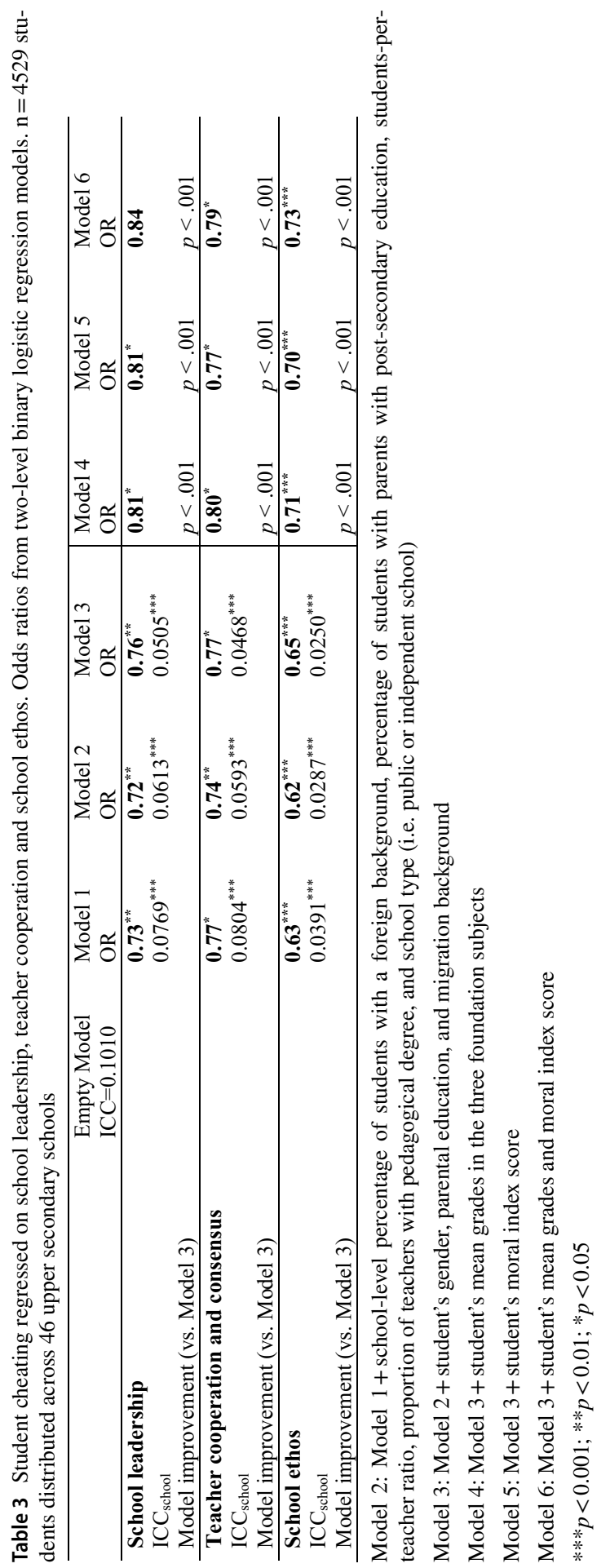


In Model 5, we replace grades by the moral index in order to explore whether the students' moral standards might serve as a mediator between our indicators of school effectiveness and student cheating. Here too, a clear drop in odds ratios visà-vis Model 3 takes place for school leadership and school ethos, but not for teacher cooperation. This suggests that students' increased tendency to cheat when their moral standards are low serves as another mediator in the association between these two features of school effectiveness and student cheating.

In Model 6, finally, we include both grades and moral index score in the model to explore the extent to which they overlap in their effect on the studied relationship. While the odds ratios for school leadership and school ethos decreases somewhat further, this is not really the case for teacher cooperation. This suggests that both grades and moral standards are important mechanisms in the association between school leadership and student cheating as well as in the association between school ethos and student cheating. While moral standards do not seem to be important for the link between teacher cooperation and student cheating, there does seem to be a small effect of grades (Model 4). Both teacher cooperation and school ethos remain with a statistically significant effect on student cheating in the final model. However, when both of the assumed mediators are controlled for, the direct effect of school leadership on student cheating is no longer significant at the $5 \%$ level. This further supports the supposition that they do serve as mediators in the studied association.

\section{Discussion}

This study examined whether higher levels of teacher-rated school effectiveness in terms of school leadership, teacher cooperation and consensus, and school ethos are associated with a lower degree of cheating among upper-secondary students in Stockholm, and whether grades and moral standards operate as mediators of these relationships. The results lent support to our first hypothesis by showing that each of the three studied school effectiveness indicators were significantly related to student cheating. Thus, the higher the teachers' average ratings of their school's effectiveness in terms of leadership, teacher cooperation and especially ethos, the less likely it is for students attending that school to cheat. These associations largely remained when sociodemographic conditions at both the student- and school-level were adjusted for, thus confirming our second hypothesis. This finding is in line with previous research showing that students' social background is of less importance for their inclination to cheat (Kerkvliet 1994; McCabe and Trevino 1997; Whitley 1998).

Research within the field of effective schools have pointed to the importance of a strong and clear school leadership, collegial cooperation between teachers as well as a prosperous school ethos for counteracting negative behaviours and improving student outcomes in a variety of areas (Grosin 2004; Rutter et al. 1979; Sellström and Bremberg 2006). Our study adds to these findings by showing that a school's adherence to the principles of effective schools also seem to counteract student cheating. An underlying idea of these principles is that the school leadership should provide the necessary conditions for processes at lower levels of the school structure 
(the classroom- and student-level) to come into force (Blair 2002). This involves having a clear and pronounced educational vision and a strategy where rules and consequences are clearly formulated and communicated to teachers and students. A teaching staff which is encouraged by the management to convey and enforce ethical behaviour among their students in a systematic manner would-from the perspective of effective schools - then be able to create a school ethos characterized by zero-tolerance towards cheating.

As stated previously, the concept of school ethos refers to the norms, values and beliefs permeating the school and manifesting themselves in the way that teachers and students relate, interact and behave towards each other (Rutter et al. 1979). It is not surprising that ethos was the strongest predictor of student cheating in this study since this could be viewed as the "end-product" of how a school is led, and thus what students actually experience in their every-day school life. If a school's ethos is characterized by a lack of concern for ethical behaviour, cheating is likely to increase and rub off on additional students, eventually becoming a normalized behaviour. Previous studies have, for example, shown that the degree of student cheating is lower in schools where there are clear rules against and consequences of such behaviour, and where the risk of detection interest is high (Bisping et al. 2008; Cizek 1999; Gire and Williams 2007; McCabe and Trevino 1993; Whitley and Keith-Spiegel 2002).

Personal characteristics and circumstances can of course also affect a student's inclination to cheat. In this study, we firstly explored whether the students' grades and moral values acted as mediators in the studied relationship, and secondly whether our three indicators of school effectiveness were linked to student cheating regardless of student grades and moral values. Results showed a clear reduction of the school effectiveness estimates when student grades were introduced in the models, thus confirming our third hypothesis that grades serve as a mediator in the studied associations. The mediating effect was however weaker for teacher cooperation, than for school leadership and school ethos. In line with previous research in this field (e.g. Rutter and Maughan 2002; Sellström and Bremberg 2006), these results suggest that students who attend schools with a strong adherence to the principles of school effectiveness tend to receive higher grades which, in turn, leads to weaker incentives to cheat (and vice versa). That students with lower grades tend to be more inclined to cheat is also something that has been demonstrated in previous research (Burrus et al. 2007; Klein et al. 2007; McCabe and Trevino 1997). Our findings add to the existing literature by showing that grades in fact seem to act as a mediator in the association between school effectiveness and student cheating.

The fourth hypothesis concerned the potentially mediating role of students' moral values in the association between school effectiveness and student cheating, and was largely confirmed as well. For teacher cooperation, however, no mediating effect of moral values could be detected in relation to student cheating. Our results nevertheless show that a school's leadership and ethos are important for shaping the moral standards of their students, and through this, their inclination to cheat. When grades and moral values were simultaneously controlled for in the final model, the estimates for both teacher cooperation and school ethos remained statistically 
significant, whereas the estimate for school leadership became non-significant. This largely confirms our fifth and final hypothesis that features of school effectiveness also have an effect on student cheating regardless of the student's personal circumstances and characteristics in terms of grades and moral values. In terms of interpretation of these findings, it seems reasonable to assume that students who cheat because they do not see any moral problems with it are more likely to express an "inherent lack of morality" (which they bring into school), whereas students who cheat despite considering it as morally wrong are more likely to have adopted this behavior in school.

Upper secondary school constitutes an important stage in life in which ethical and moral values are shaped for the future. The degree to which the school manages to convey and enforce ethical behaviour is vital for their students' chances of developing a sound "moral compass" to guide them in their future choices and decisions, and for their prospects of becoming a trusted colleague and a good citizen along their continued life-path. Previous research has shown that immoral acts such as cheating are likely to spill over into other social contexts (Bower 1964) and that cheating during upper secondary school is linked to future unethical actions, both in further education and later in working life (Carpenter et al. 2004; Graves 2011; Lucas and Friedrich 2005; Lawson 2004; Whitley 1998).

The presence of cheating within the educational system also has equity implications. Here, the most apparent injustice is the fact that students who refrain from cheating are disfavoured vis-à-vis those who "successfully" cheat when it comes to allocation of higher education places. Besides the obvious injustice that such a state of affair involves for the non-cheating students, it also risks undermining education as an institution for fair allocation of future life opportunities. Another unjustness concerns those who actually develop a cheating behavior in school and the longterm consequences that this may entail for the individual student (Carpenter et al. 2004; Graves 2011; Lucas and Friedrich 2005; Lawson 2004; Whitley 1998). In our study, we found tangible differences between schools in the proportion of students who cheated $(\mathrm{ICC}=10 \%)$. This variation was to a large extent accounted for by differing degrees of adherence to our school effectiveness indicators, especially school ethos. Thus, depending on which school a student attends, he or she will run a greater or lesser risk of developing a cheating behaviour, which could be regarded as an injustice in its own right.

Research has shown that student cheating can be activated by perceiving that many of one's peers tend to cheat and get away with it (McCabe et al. 2012; O'Rourke et al. 2010). School environments with a strong emphasis on competition and achievement have also been found to evoke cheating behavior in the student population (Anderman and Koenka 2017; Anderman and Midgley 2004). At the structural level too, Fonseca (2014) argues that an educational system characterized by competition and market-forces is likely to increase student cheating. The present study was conducted within Stockholm's upper secondary school market, which is characterized by far-reaching market adaptations and competition between schools, which means that studies in other contexts are needed in order to broaden the knowledge about how various features of school effectiveness are related to student cheating. 


\subsection{Strengths and limitations}

A major strength of our study design is the combination of data from two separate sources, as well as the access to official statistics about the school's sociodemographic composition. Since school effectiveness was measured by teachers' ratings, and cheating was reported by the students themselves, this considerably reduces the risk bias due to common methods variance. In this study we used a conservative cut-off for student cheating (four times or more during the past school year), which could be questioned. The main reason for this decision was based on the assumption that students with low grades and/or low moral standards cheat more frequently and systematically. However, sensitivity analyses using measures of cheating with less conservative cut-offs revealed very similar results to the ones presented in this study.

As suggested in previous research (Cassady 2001), there is always a risk of bias in self-reported data. This may especially concern student cheating since individuals tend to underestimate their degree of socially undesirable behaviours (Kerkvliet 1994). However, we do not see any particular reason why such a bias would have affected the investigated relationships with our teacher-rated measures of school effectiveness. The results from this study should nevertheless be considered with some limitations in mind. First, the findings are based on eleventh grade students in Stockholm municipality, which means that generalizations to other geographical contexts and ages should be made with caution. Secondly, the study builds on cross-sectional data, preventing us from making any conclusions regarding causality. A certain amount of reverse causality may exist due to a possible selection of cheating students to schools with lower levels of adherence to school effectiveness. It would be desirable to explore this question further based on longitudinal data. Third, there are more advanced statistical ways of investigating mediating effects. The model used (Baron and Kenny 1986) is nevertheless a well-established tool for investigating potential mediating effects. Fourth, we are aware of the limitations of using self-reported grades from students (Cassady 2001). However, we have compared our data on grades with corresponding statistics retrieved from the Swedish National Agency for Education for all upper secondary students in Stockholm, and the distributions did not differ to any substantial degree.

Finally, approximately one third of the students in our sample stated that they had cheated at least once on a homework test or examination during the present school year. This is a lower proportion than reported in other studies, predominantly from the US, where as many as two thirds declared having cheated (Davis et al. 2011; Josephson Institute 2012; McCabe et al. 2012). The lower rate of self-reported cheating in our data may be due to a narrower definition, since we only asked about cheating on homework tests or examinations, while other studies also include cheating through, for example, plagiarism. Other studies have also found that the degree of cheating is lower in Scandinavian countries than most other nations (Teixeira and Rocha 2010).

\subsection{Conclusions}

In this study we have pointed to the importance of three school contextual characteristics for student cheating. Schools with high teacher-ratings on leadership, 
collegial cooperation and ethos, were found to have a lower degree of cheating among their students. We also found evidence that student grades and moral standards operate as mediators in the relation between school effectiveness and student cheating. Targeting organizational factors that strengthen these school contextual conditions is likely to lower the level of cheating among students. Reducing the level of cheating is, in turn, an important prerequisite for creating a more equitable allocation of educational opportunities, and for preventing individual students from "down-grading" their moral compass during their schooling.

Funding This work was financially supported by Vetenskapsrådet, Forte, Formas and Vinnova [2014-10107].

Open Access This article is distributed under the terms of the Creative Commons Attribution 4.0 International License (http://creativecommons.org/licenses/by/4.0/), which permits unrestricted use, distribution, and reproduction in any medium, provided you give appropriate credit to the original author(s) and the source, provide a link to the Creative Commons license, and indicate if changes were made.

\section{References}

Anderman, E. M., \& Koenka, A. C. (2017). The relation between academic motivation and cheating. Theory Into Practice, 56(2), 95-102.

Anderman, E. M., \& Midgley, C. (2004). Changes in self-reported academic cheating across the transition from middle school to high school. Contemporary Educational Psychology, 29(4), 499-517.

Arnett, J. L., Arnett, J. J., Feldman, S. S., \& Cauffman, E. (2002). It's wrong, but everybody does it: Academic dishonesty among high school and college students. Contemporary Educational Psychology, 27(2), 209-228.

Baron, R. M., \& Kenny, D. A. (1986). The moderator-mediator variable distinction in social psychological research: Conceptual, strategic, and statistical considerations. Journal of Personality and Social Psychology, 51(6), 1173.

Bernardi, R. A., Baca, A. V., Landers, K. S., \& Witek, M. B. (2008). Methods of cheating and deterrents to classroom cheating: An international study. Ethics and Behavior, 18(4), 373-391.

Bisping, T. O., Patron, H., \& Roskelley, K. (2008). Modeling academic dishonesty: The role of student perceptions and misconduct type. The Journal of Economic Education, 39(1), 4-21.

Blair, M. (2002). Effective school leadership: The multi-ethnic context. British Journal of Sociology of Education, 23(2), 179-191.

Bowers, W. J. (1964). Student dishonesty and its control in college. New York: Bureau of Applied Social Research, Columbia University.

Burrus, R. T., McGoldrick, K., \& Schuhmann, P. W. (2007). Self-reports of student cheating: Does a definition of cheating matter? The Journal of Economic Education, 38(1), 3-16.

Carpenter, D. D., Harding, T. S., Finelli, C. J., \& Passow, H. J. (2004). Does academic dishonesty relate to unethical behavior in professional practice? An exploratory study. Science and Engineering Ethics, 10(2), 311-324.

Cassady, J. C. (2001). Self-reported GPA and SAT: A methodological note. Practical assessment, research \& evaluation, 7(12), 1-6.

Cizek, G. J. (1999). Cheating on tests: How to do it, detect it, and prevent it. Mahwah, NJ: Erlbaum.

Davis, S. F., Drinan, P. F., \& Gallant, T. B. (2011). Cheating in school: What we know and what we can do. West Sussex, UK: Wiley.

Day, N. E., Hudson, D., Dobies, P. R., \& Waris, R. (2011). Student or situation? Personality and classroom context as predictors of attitudes about business school cheating. Social Psychology of Education, 14(2), 261-282.

Djurfeldt, G., \& Barmark, M. (2009). Statistisk verktygslåda 2: multivariat analys [Statistical toolkit 2: multivariate analysis]. Lund: Studentlitteratur. 
Farnese, M. L., Tramontano, C., Fida, R., \& Pacielo, M. (2011). Cheating behaviors in academic context: Does academic moral disengagement matter? Procedia-Social and Behavioral Sciences, 29, 356-365.

Fonseca, L. (2014). Det godkända fusket: Normförhandlingar i gymnasieskolans bedömningspraktiker [Cheating by Consent - norm negotiations in assessment practices of upper secondary schools] (Doctoral dissertation, Linnaeus University Press).

Gibson, C. L., Khey, D., \& Schreck, C. J. (2008). Gender, internal controls, and academic dishonesty: Investigating mediating and differential effects. Journal of Criminal Justice Education, 19(1), 2-18.

Gire, J. T., \& Williams, T. D. (2007). Dissonance and the honor system: Extending the severity of threat phenomenon. The Journal of Social Psychology, 147(5), 501-509.

Granvik Saminathen, M., Brolin Låftman, S., Almquist, Y. B., \& Modin, B. (2018). Effective schools, school segregation, and the link with school achievement. School Effectiveness and School Improvement, $1-21$.

Graves, S. M. (2011). Student cheating habits: A predictor of workplace deviance. Journal of Diversity Management, 3(1), 15-22.

Grosin, L. (2004). Skolklimat, prestation och anpassning i 21 mellan-och 20 högstadieskolor [School climate, perfromance and adjustment in 21 intermediate and 20 senior level schools] (Research Report No. 71). Sweden, Stockholm: Pedagogiska Institutionen.

Hensley, L. C., Kirkpatrick, K. M., \& Burgoon, J. M. (2013). Relation of gender, course enrollment, and grades to distinct forms of academic dishonesty. Teaching in Higher Education, 18(8), 895-907.

Institute, Josephson. (2012). Josephson Institute's 2012 report card on the ethics of American youth. Los Angeles, CA: Josephson Institute of Ethics.

Jereb, E., Urh, M., Jerebic, J., \& Šprajc, P. (2018). Gender differences and the awareness of plagiarism in higher education. Social Psychology of Education, 21(2), 409-426.

Kerkvliet, J. (1994). Cheating by economics students: A comparison of survey results. The Journal of Economic Education, 25(2), 121-133.

Klein, H. A., Levenburg, N. M., McKendall, M., \& Mothersell, W. (2007). Cheating during the college years: How do business school students compare? Journal of Business Ethics, 72(2), 197-206.

Låftman, S. B., Östberg, V., \& Modin, B. (2017). School leadership and cyberbullying: A multilevel analysis. International Journal of Environmental Research and Public Health, 14(10), 1226.

Lawson, R. A. (2004). Is classroom cheating related to business students' propensity to cheat in the" real world"? Journal of Business Ethics, 49(2), 189-199.

Lucas, G. M., \& Friedrich, J. (2005). Individual differences in workplace deviance and integrity as predictors of academic dishonesty. Ethics and Behavior, 15(1), 15-35.

Lundahl, C. (2010). Skolbedömningens pedagogiska och administrativa dimensioner [The school assessment's educational and administrative dimensions]. In C. Lundahl \& M. Fichtelius (Eds.). Bedömning i och av skolan [Assessment in and of school]. Lund: Studentlitteratur.

Lundahl, L., Arreman, I. E., Holm, A. S., \& Lundström, U. (2014). Gymnasiet som marknad [Upper Secondary School as a market]. Umeå: Boréa.

McCabe, D. L., Butterfield, K. D., \& Trevino, L. K. (2012). Cheating in college: Why students do it and what educators can do about it. Baltimore, MD: John Hopkins University Press.

McCabe, D. L., \& Trevino, L. K. (1993). Academic dishonesty: Honor codes and other contextual influences. The Journal of Higher Education, 64(5), 522-538.

McCabe, D. L., \& Trevino, L. K. (1997). Individual and contextual influences on academic dishonesty: A multicampus investigation. Research in Higher Education, 38(3), 379-396.

McCabe, D. L., Trevino, L. K., \& Butterfield, K. D. (1999). Academic integrity in honor code and nonhonor code environments: A qualitative investigation. The Journal of Higher Education, 70(2), 211-234.

McCabe, D. L., Trevino, L. K., \& Butterfield, K. D. (2001). Cheating in academic institutions: A decade of research. Ethics and Behavior, 11(3), 219-232.

Miller, A. D., Murdock, T. B., Anderman, E. M., \& Pointdexter, A. L. (2007). Who are all these cheaters? Characteristics of academically dishonest students. In E. M. Anderman \& T. B. Murdock (Eds.), Psychology of academic cheating (pp. 9-32). Amsterdam: Elsevier Academic Press.

Modin, B., Låftman, S. B., \& Östberg, V. (2017). Teacher rated school ethos and student reported bullying - A multilevel study of upper secondary schools in Stockholm, Sweden. International Journal of Environmental Research and Public Health, 14(12), 1565.

Mood, C. (2010). Logistic regression: Why we cannot do what we think we can do, and what we can do about it. European Sociological Review, 26(1), 67-82. 
Mori, S. C. (2000). Addressing the mental health concerns of international students. Journal of Counseling \& Development, 78(2), 137-144.

Muijs, D. (2011). Leadership and organisational performance: From research to prescription? International Journal of Educational Management, 25, 45-60.

Niiya, Y., Ballantyne, R., North, M. S., \& Crocker, J. (2008). Gender, contingencies of self-worth, and achievement goals as predictors of academic cheating in a controlled laboratory setting. Basic and Applied Social Psychology, 30(1), 76-83.

Nilsson, L. E., Eklöf, A., \& Ottosson, T. (2004). Cheating as a preparation for reality. In 32nd Congress of the Nordic Educational Research Association (NERA), Reykjavik, Iceland.

O'Rourke, J., Barnes, J., Deaton, A., Fulks, K., Ryan, K., \& Rettinger, D. A. (2010). Imitation is the sincerest form of cheating: The influence of direct knowledge and attitudes on academic dishonesty. Ethics and Behavior, 20(1), 47-64.

Ramberg, J. (2015). Special education in Swedish upper secondary schools: Resources, ability grouping and organisation (Doctoral dissertation, Department of Special Education, Stockholm University).

Ramberg, J., Låftman, S. B., Almquist, Y. B., \& Modin, B. (2018b). School effectiveness and students' perceptions of teacher caring: A multilevel study. Improving Schools, pp. 1-17.

Ramberg, J., Låftman, S. B., Fransson, E., \& Modin, B. (2018a). School effectiveness and truancy: A multilevel study of upper secondary schools in Stockholm. International Journal of Adolescence and Youth, 1-14.

Rutter, M., \& Maughan, B. (2002). School effectiveness findings 1979-2002. Journal of School Psychology, 40(6), 451-475.

Rutter, M., Maughan, B., Mortimore, P., Ouston, J., \& Smith, A. (1979). Fifteen thousand hours: Secondary schools and their effects on children. London, England: Open Books.

Scheerens, J. (2016). Educational effectiveness and ineffectiveness. A critical review of the knowledge base. Dordrecht, The Netherlands: Springer.

Schmelkin, L. P., Gilbert, K., Spencer, K. J., Pincus, H. S., \& Silva, R. (2008). A multidimensional scaling of college students' perceptions of academic dishonesty. The Journal of Higher Education, 79(5), 587-607.

Sellström, E., \& Bremberg, S. (2006). Is there a "school effect" on pupil outcomes? A review of multilevel studies. Journal of Epidemiology and Community Health, 60(2), 149-155.

SFS 2010:800 Education Act 2010/800. Stockholm: Ministry of Education and Research.

SFS 2010:2039 Upper Secondary School Ordinance 2010/2039. Stockholm: Ministry of Education and Research.

Shariffuddin, S. A., \& Holmes, R. J. (2009). Cheating in examinations: a study of academic dishonesty in a Malaysian college. Asian Journal of University Education, 5(2), 99-124.

Smith, K. J., Davy, J. A., \& Easterling, D. (2004). An examination of cheating and its antecedents among marketing and management majors. Journal of Business Ethics, 50(1), 63-80.

Smith, K. J., Davy, J. A., Rosenberg, D. L., \& Haight, G. T. (2002). A structural modeling investigation of the influence of demographic and attitudinal factors and in-class deterrents on cheating behavior among accounting majors. Journal of Accounting Education, 20(1), 45-65.

Swedish Higher Education Ordinance. (2002/2010). Swedish Higher Education Act 2002:2010. Fritzes: Stockholm.

Swedish National Agency for Education. (2016). Official statistics retrieved from: https://www.skolverket .se/skolutveckling/statistik/om-skolverkets-statistik Accessed 25 Oct 2018.

Teddlie, C., \& Reynolds, D. (2000). The international handbook of school effectiveness research. London: Falmer Press.

Teixeira, A. A., \& Rocha, M. F. (2010). Cheating by economics and business undergraduate students: An exploratory international assessment. Higher Education, 59(6), 663-701.

Van Waes, S., Moolenaar, N. M., Daly, A. J., Heldens, H. H., Donche, V., Van Petegem, P., et al. (2016). The networked instructor: The quality of networks in different stages of professional development. Teaching and Teacher Education, 59, 295-308.

Vangrieken, K., Dochy, F., Raes, E., \& Kyndt, E. (2015). Teacher collaboration: A systematic review. Educational Research Review, 15, 17-40.

Whitley, B. E. (1998). Factors associated with cheating among college students: A review. Research in Higher Education, 39(3), 235-274.

Whitley, B. E., \& Keith- Spiegel, P. (2002). Academic dishonesty: An educator's guide. Mahwah, NJ: Erlbaum. 
Wowra, S. A. (2007). Moral identities, social anxiety, and academic dishonesty among American college students. Ethics and Behavior, 17(3), 303-321.

Wu, S., Crespi, C. M., \& Wong, W. K. (2012). Comparison of methods for estimating the intraclass correlation coefficient for binary responses in cancer prevention cluster randomized trials. Contemporary Clinical Trials, 33(5), 869-880.

Yu, H., Glanzer, P. L., Sriram, R., Johnson, B. R., \& Moore, B. (2017). What contributes to college students' cheating? A study of individual factors. Ethics and Behavior, 27(5), 401-422.

Publisher's Note Springer Nature remains neutral with regard to jurisdictional claims in published maps and institutional affiliations.

Joacim Ramberg is a post-doctoral researcher with a Ph.D. in Special Education. His research interests revolve around issues such as inclusive education, democracy, social justice, school effectiveness and the learning environment within schools and education systems.

Bitte Modin is a professor of Medical Sociology. She has studied both short- and long-term health implications of children's early social environment. Her current research largely focuses on how various aspects of the school environment are linked to young people's health and wellbeing in Sweden and other countries. 